\title{
Groundnut Production Performance in Bangladesh: A District Level Analysis
}

\author{
Uttam Deb and Soumitra Pramanik \\ ICRISAT, Patancheru 502324, Telangana, India \\ Corresponding author: uttamkumardeb@gmail.com
}

Paper No.: 239 Received: 4 June 2015

Accepted: 16 September 2015

\begin{abstract}
This study analyzes the performance of groundnut production in Bangladesh in the 1990s and 2000s, both at the district and national level. Production performance was measured in terms of growth and variability. Annual compound rate of growth was estimated to know the growth performance. Cuddy-Della Valle index was used to estimate variability. Analysis showed that both area and production of groundnut at the national level declined in the 1990s but production increased afterwards. In the late 2000s, groundnut production increased by $31 \%$ although area under groundnut was same as in the late 1990s. Increase in groundnut yield (by $373 \mathrm{~kg} / \mathrm{ha}$ or $32 \%$ ) contributed towards increase in groundnut production in the late 2000s. In the late 2000s (TE2009/10), top five groundnut producing districts (Noakhali, Dhaka, Faridpur, Kishoreganj and Pabna) accounted for 59 percent of area and 55 percent of production. In the 2000s, Bangladesh achieved high annual growth (5.0\% or more) in groundnut production at the national level and in nine districts (Faridpur, Tangail, Barisal, Jessore, Kushtia, Dinajpur, Pabna, Rangpur and Chittagong H.T.). On the other hand, variability in groundnut production in the 2000s increased insignificantly at the national level while three districts (Sylhet, Mymensingh and Tangail) experienced statistically significant increase in variability in groundnut production. Increase in variability in groundnut production was mainly due to the increased variability in area under groundnut indicating that the crop was expanded to less suitable areas. The study concludes that groundnut breeders should focus more on yield increase rather than on reduction in variability in yield. Increase in yield potential through research is expected to have higher production and profit to the farmers and thereby, encourage farmers to allocate more area under groundnut cultivation.
\end{abstract}

Keywords: Bangladesh, groundnut, production, growth, variability

Policy makers and agricultural research managers always want to know the production performance of different crops grown in the country. Information about production performance of a crop in different regions helps us to design intervention measures to improve the overall performance of the crop. It is essential to formulate research strategies for crop improvement, undertake policy measures and develop plans to ensure availability and sustain production. Production performance has two important indicators: growth and variability. Estimates on growth in area, production and yield help us to understand how production is changing over time, what are the driving forces behind the changes in production productivity or area under the crop. On the other hand, estimates on variability help us to know the nature and extent of instability and risk in the production process. Identification of sources of variability in production is useful to know the causal factors and find ways to minimize risks and thereby, increase production.

The issue of growth and variability in crop production has attracted many scholars. A causal link between growth in agricultural production and instability was first addressed by Sen (1967). His hypothesis was that variability in production increases due to expansion of cultivation to the marginal land and the increased use of purchased inputs. Rao (1975), however, described that since variability in yield tends to be far greater than variability in area, shifting from growth based on expanding area to growth based on increasing yields automatically leads to a tendency toward increased variability in production. Hazell (1989) observed that production variability in world 
cereal production increased since the rapid adoption of modern technology. Mehra (1981) also argues that instability in India's total food grain production has increased due to the widespread adoption of the improved seed-fertilizer intensive technologies since the mid-1960s. Similar arguments are also put forward by Rao (1975), by Barker, Gabler and Winckelmann (1981) and by Griffin (1988). Carlson (1985) examined the causes of rice yield variability using panel data from 13 Asian countries. He concluded that the coefficients of variation of both rice yields and total production decreased significantly with higher adoption of modern varieties and irrigation development. Deb, Joshi and Bantilan (1999) showed that the expansion of modern sorghum cultivars in India helped to increase sorghum yield and reduced the relative variability in yield. McIntire and Fussell (1985) estimated sources of variation in millet grain yield from farm level data in India. The results showed that improved cultivars did not generally contribute to increased relative or absolute variability if accompanied by appropriate package of inputs. Singh and Byerlee (1990), based on 57 wheat producing countries of the world, showed that relative variability in wheat yield declined over time and expansion of modern wheat varieties have positive contribution to the decrease in variability in wheat yield. Deb, Mandal and Dey (1991), based on secondary data from Bangladesh for the period 1947/48 to 1986/87, analyzed production variability for six crops including groundnut for two periods, modern technology period (1968/691986/87) and pre-modern technology period (1947/48$1967 / 68)$. They found that both the absolute and relative variability in production reduced during the modern technology period compared to the pre-modern technology period. They have measured the absolute variability through standard deviation and variance, and relative variability through coefficient of variation. The major limitation of their study lies in the use of simple coefficient of variation. The simple coefficient of variation over-estimates the level of instability in timeseries data.

Although at the theoretical level it is suggested that the questions of stability - and adaptability should be properly distinguished (Evenson et al., 1979), empirical analysis of the issue mainly proceeds in terms of measurement of variability in production and yield based on time series data. However, it is shown that when such measures are compared for different periods, the conclusions appear to be sensitive to changes in cutoff points and dropping of observations for 'unusual' years (Alauddin and Tisdell, 1988).
Deb, Bose and Dey (1999) estimated variability in area, production and yield of sugarcane in Bangladesh for 1962/- 63 to 1993/94, both at the national and district level. The study reported that sugarcane area and production in Bangladesh has increased over time while the yield has decreased. There was no significant change in variability in sugarcane production, area and yield in succeeding periods in Bangladesh though different districts showed a mixed pattern.

Ragavendra (2006) showed that groundnut production had an annual growth of 2.4 percent while groundnut area grew at the rate of 1.17 percent and yield grew at 1.22 percent in the pre-WTO period (1985-1994). On the other hand, performance of groundnut in Karnataka in the post WTO period (1995-2004) was dismal with negative trends. Patil et al. (2009) observed that groundnut production has declined in Maharashtra at the rate of 4.10 percent per annum during 1993/94 to 2006/07 due to the decline in both area and yield. During the same period, groundnut production in India declined by $3.10 \%$ per annum mainly due to decrease in area.

Groundnut is a very important crop in Bangladesh. It is used as edible oil, to make cake, biscuit and bakery in the food industries. Traditionally it is eaten as fried 'badam' and oil cake is used as cattle feed. Bangladesh import groundnut oil and shelled groundnut on a regular basis. In 2008, Bangladesh imported 27 metric tons of groundnut oil spending USD \$100 thousand (FAOSTAT, 2011). The soil and climate of Bangladesh are quite suitable for groundnut production. It is cultivated mostly in sandy soils and riverbeds (Nath and Alam, 2002). In spite of its importance as an oil crop and of multifarious uses in everyday life, there is lack of information about its production performance across different districts in Bangladesh. Information about the growth performance and variability situation in groundnut production would help the policy makers of Bangladesh to implement policy measures such as export-import policy for groundnut. This paper tries to assess the performance in groundnut production in Bangladesh at the national and district level during the last two decades, 1990s and 2000s. The specific objectives of the study are (1) to analyze spatial and temporal performance of groundnut production in Bangladesh; (2) to estimate the level of variability in groundnut production and its sources in different districts of Bangladesh during the 1990s and 2000s; and (3) to discuss implications of research findings for agricultural policy and crop improvement to enhance groundnut production in Bangladesh. 


\section{Database and Methodology}

The analysis is based on secondary data on groundnut area and production collected from various issues of the Year Book of Agricultural Statistics of Bangladesh published by the Bangladesh Bureau of Statistics. We have analyzed groundnut production performance in 20 greater or old districts which had at least 40 hectares under groundnut in all years during 1990/91 to 2009/10. Khulna district was not included in the analysis since its total groundnut area in a year was often less than 40 hectares. The study districts are: Barisal, Bogra, Chittagong, Chittagong H.T., Comilla, Dhaka, Dinajpur, Faridpur, Jamalpur, Jessore, Kishoreganj, Kushtia, Mymensingh, Noakhali, Pabna, Patuakhali, Rajshahi, Rangpur, Sylhet and Tangail.

We have carried out analysis of growth and variability in groundnut production, area, and yield for two periods: 1990s (1990/91-1999/2000) and 2000s (2000/01-2009/10). Annual compound rate of growth in area, production and yield of groundnut was estimated using equation (1) and (2):

$$
\ln Y=a+b t
$$

Where $\ln \mathrm{Y}$ is the area (in hectares)/production (metric tons)/per hectare yield of groundnut (in $\mathrm{kg}$ ) expressed in natural log form, $t$ is the time trend denoting years and $b$ is the regression coefficient.

$$
\text { Compound growth rate }(\mathrm{g})=\operatorname{Exp}(\mathrm{b})-1
$$

Variability in area, production and yield of groundnut is measured in relative terms by the CuddyDella Valle index which is used as a measure of variability in time-series data (e.g., Weber and Sievers, 1985; Singh and Byerlee, 1990; Deb et al., 1999). The simple coefficient of variation over-estimates the level of instability in time-series data characterized by long-term trends whereas the Cuddy-Della Valle index corrects the coefficient of variation, by:

$$
\mathrm{CV}=\left(\mathrm{CV}^{*}\right)\left(1-\mathrm{R}^{2}\right)^{0.5}
$$

Where CV is the Cuddy-Della Valle index, i.e., corrected coefficient of variation (CV). Henceforth, any mention of $C V$ would refer to the Cuddy Della Valle Index.

$\mathrm{CV}^{*}$ is the simple estimate of the coefficient of variation (in percent), and $R^{2}$ is the coefficient of determination from a time-trend regression adjusted by the number of degrees of freedom. It may be mentioned here that some authors have estimated the $\mathrm{CV}$ around trend as the standard error of regression divided by mean. After estimating in both ways from the same set of data, Singh and Byerlee (1990) found that the results are almost identical whichever method is used. In their case, the correlation between the instability indices of two methods was 0.9998 . Since both methods provide same results, we opted to estimate instability index using Cuddy Della Valle Index. To determine whether the differences in CVs between periods from individual observations, i, are statistically significant or not, we used the approach of Anderson and Hazell (1989) based on Kendall and Stewart (1969, p. 233, 243), where a standard normal test statistic, Z, is calculated by;

$$
\mathrm{Z}=\left(\mathrm{CV}_{2}-\mathrm{CV}_{1}\right) / \mathrm{D}
$$

Where $\mathrm{D}$ is defined as,

$$
\mathrm{D}=\mathrm{c}\left\{\left[\left(1+2 \mathrm{c}^{2}\right) / 2\right]\left(1 / \mathrm{n}_{1}+1 / \mathrm{n}_{2}\right)\right\}^{0.5}
$$

where $\mathrm{CV}_{\mathrm{i}}$ is the $\mathrm{CV}$ in period i of length $n_{\mathrm{i}}$ years, and $\mathrm{c}$ is the $\mathrm{CV}$ in the parent population. We have approximated c by $\mathrm{CV}_{1}$ following Anderson and Hazell (1987). The change in $\mathrm{CV}$ for each district was tested using the Central Limit Theorem to compute $\mathrm{Z}^{*}=\mathrm{SZ}_{\mathrm{i}} / \mathrm{m}^{0.5}$, where $Z_{i}$ are the standard normal test statistics for each observation of equation (4) above, and $\mathrm{m}$ is the number of observations in the sample.

\section{Results and Discussion}

Table 1 shows the contribution of different districts to total groundnut area, and production in three different periods; early 1990s (1990/91-1992/93), late 1990s (1999/00-2001/02) and late 2000s (2007/08-2009/10). During early 1990s, average annual groundnut area in Bangladesh was 37.75 thousand hectares while total production was 40.82 thousand metric tons. Both the average area and production of groundnut decreased to 30.45 thousand hectares and 34.63 thousand metric tons, respectively, during late 1990s compared to early 1990s. In late 2000s, average groundnut area and production in Bangladesh was 30.16 thousand hectares and 45.20 thousand metric tons, respectively (Figure 1 ). In the late 2000s, top five groundnut growing districts (Noakhali, Faridpur, Dinajpur, Dhaka and Chittagong) accounted for 58 percent of production and 60 percent of groundnut area in Bangladesh. During this period, Chittagong H.T., Kushtia, and Rajshahi district contributed less than one percent to the total groundnut production in Bangladesh.

Table 2 presents the yield level in different districts. Over time, average yield level of groundnut in Bangladesh has increased (Figure 2). Per hectare yield level of 
groundnut has increased in Bangladesh in late 1990s compared to early 1990 s by $4.5 \%$. Also in late 2000 s compared to early 1990s the yield level increased by 39.0 percent $(422 \mathrm{~kg}$ ). During the late 2000s, compared to early 1990s, yield level in ten districts have increased more than 40 percent and in six districts more than $15 \%$. Highest yield level increased in Barisal district recorded $128 \%$. While yield has decreased only in four districts, in Rajshahi district it decreased to $69 \%$.
Using equation (2), we have estimated the annual compound rate of growth in area, production and yield of groundnut in different districts of Bangladesh for the three periods mentioned earlier. Table 3 presents the estimated growth rates. Based on the annual compound rates of growth, study districts can be classified into four categories: Category A (High growth): districts achieved growth rate $5 \%$ or above; Category $\mathrm{B}$ (Moderate growth): districts achieved growth rate more than $1 \%$ but less

Table 1: Area and production of groundnut in different districts of Bangladesh 1990-2010

\begin{tabular}{|c|c|c|c|c|c|c|}
\hline \multirow[t]{2}{*}{ Districts } & \multicolumn{3}{|c|}{ Average Area (hectares) } & \multicolumn{3}{|c|}{ Average Production (M Ton) } \\
\hline & Early 90s & Late 90s & Late 2000s & Early 90s & Late 90s & Late 2000s \\
\hline Barisal & $1950(5.17)$ & $2054(6.75)$ & $1304(4.32)$ & $1632(4.00)$ & $1807(5.22)$ & $2485(5.50)$ \\
\hline Bogra & $1061(2.81)$ & $1423(4.67)$ & $526(1.74)$ & $1672(4.10)$ & $2047(5.91)$ & $748(1.66)$ \\
\hline Chittagong & $1054(2.79)$ & $1237(4.06)$ & $1175(3.90)$ & $1390(3.41)$ & $1983(5.73)$ & $2877(6.37)$ \\
\hline Chittagong H.T. & $288(0.76)$ & $76(0.25)$ & $167(0.56)$ & $552(1.35)$ & $87(0.25)$ & $234(0.52)$ \\
\hline Comilla & $1744(4.62)$ & $1978(6.50)$ & $735(2.44)$ & $2492(6.10)$ & $2698(7.79)$ & $1002(2.22)$ \\
\hline Dhaka & $3211(8.51)$ & $4110(13.50)$ & $2067(6.85)$ & $3472(8.50)$ & $3250(9.39)$ & $3144(6.96)$ \\
\hline Dinajpur & $45(0.12)$ & $81(0.27)$ & $2325(7.71)$ & $28(0.07)$ & $82(0.24)$ & $3530(7.81)$ \\
\hline Faridpur & $4827(12.79)$ & $1806(5.93)$ & $4624(15.33)$ & $6050(14.82)$ & $1185(3.42)$ & $7081(15.67)$ \\
\hline Jamalpur & $1196(3.17)$ & $734(2.41)$ & $516(1.71)$ & $1218(2.98)$ & $1197(3.46)$ & $1191(2.63)$ \\
\hline Jessore & $376(1.00)$ & $165(0.54)$ & $647(2.14)$ & $377(0.92)$ & $168(0.49)$ & $1251(2.77)$ \\
\hline Kishoreganj & $2978(7.89)$ & 3033 (9.96) & $1648(5.46)$ & $3788(9.28)$ & $4908(14.18)$ & $2439(5.40)$ \\
\hline Kushtia & $180(0.48)$ & $123(0.40)$ & $301(1.00)$ & $173(0.42)$ & $137(0.39)$ & $378(0.84)$ \\
\hline Mymensingh & $643(1.70)$ & $636(2.09)$ & $401(1.33)$ & $698(1.71)$ & $877(2.53)$ & $484(1.07)$ \\
\hline Noakhali & $10449(27.68)$ & $7747(25.44)$ & $7762(25.74)$ & $9193(22.52)$ & $8545(24.68)$ & $9645(21.34)$ \\
\hline Pabna & $426(1.13)$ & $331(1.09)$ & $1712(5.68)$ & $573(1.40)$ & $433(1.25)$ & $2739(6.06)$ \\
\hline Patuakhali & $1271(3.37)$ & $1158(3.80)$ & $618(2.05)$ & $1102(2.70)$ & $1332(3.85)$ & $676(1.50)$ \\
\hline Rajshahi & $181(0.48)$ & $352(1.16)$ & $182(0.60)$ & $780(1.91)$ & $520(1.50)$ & $238(0.53)$ \\
\hline Rangpur & $4333(11.48)$ & 1909 (6.27) & $1327(4.40)$ & $4350(10.66)$ & $1437(4.15)$ & $2001(4.43)$ \\
\hline Sylhet & $1464(3.88)$ & $1321(4.34)$ & $844(2.80)$ & $1680(4.12)$ & $1763(5.09)$ & $1357(3.00)$ \\
\hline Tangail & $125(0.33)$ & $167(0.55)$ & $1248(4.14)$ & $112(0.27)$ & $152(0.44)$ & $1623(3.59)$ \\
\hline Bangladesh & $37748(100.00)$ & $30449(100.00)$ & $30158(100.00)$ & $40820(100.00)$ & $34627(100.00)$ & $45192(100.00)$ \\
\hline
\end{tabular}

Notes: 1. Early 1990s, late 1990s and late 2000s refer to the crop yearS, 1990/91- 1992/93, 1999/00- 2001/02 and 2007/08- 2009/10

2. Figures in the parentheses are the percentages of total area and production in Bangladesh.

Source: Authors' calculation, based on data collected from BBS.

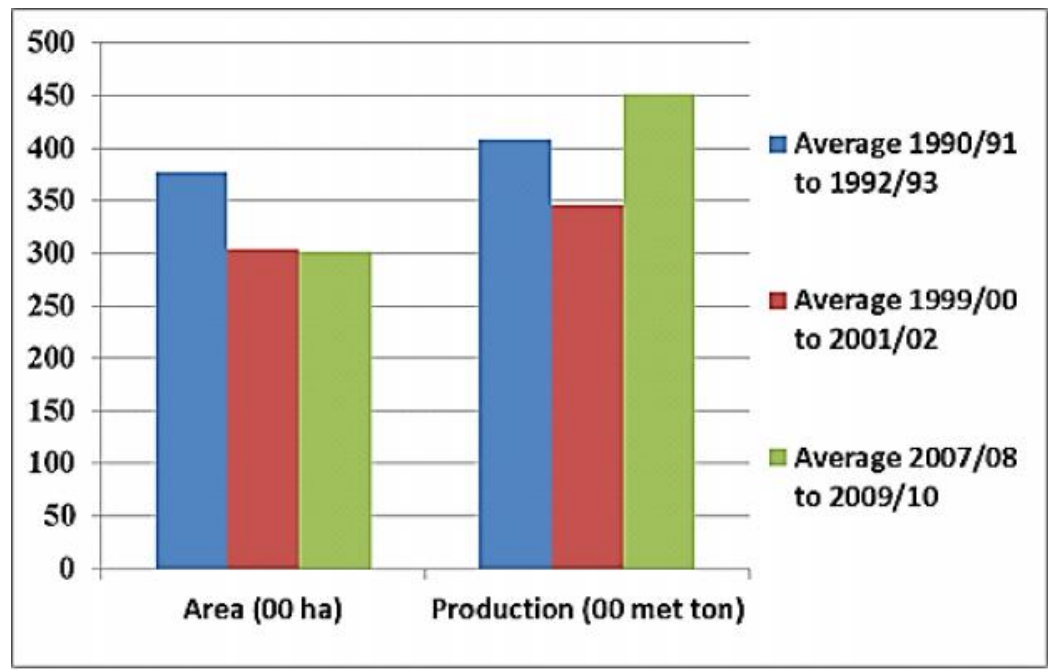

Fig. 1: Trends in Area and Production of Groundnut in Bangladesh, 1990/91 to 2009/10

Source: Authors' calculation, based on data collected from BBS 
than 5\%; Category C (Slow growth): districts achieved positive growth rate up to $1 \%$; Category D (Negative growth): districts experienced negative rate of growth rate in groundnut area, production and yield in the reference period.

Bangladesh at the national level had negative growth in both area and production of groundnut in the 1990s but registered positive growth in area (1.11 percent) and high growth in production (5.13 percent) in the 2000s. Annual compound rate of growth in groundnut yield in Bangladesh was 1.11 percent in the 1990s and 3.98 percent in the 2000s. During 1990s, two districts (Dinajpur and Rajshahi) experienced high rate of growth in area while another district (Kishoreganj) had high growth rate in production whereas only two districts (Dinajpur and Kishoreganj) experienced high growth in yield. During this period, 10 districts (Noakhali, Sylet, Faridpur, Jamalpur, Mymensingh,

Table 2: Groundnut yield in different districts of Bangladesh

\begin{tabular}{|c|c|c|c|c|c|}
\hline \multirow[t]{2}{*}{ Districts } & \multicolumn{3}{|c|}{ Average Yield (Kg/Ha) } & \multicolumn{2}{|c|}{$\%$ change in average yield during period } \\
\hline & Early 1990s & Late 1990s & Late 2000s & $\begin{array}{c}\text { Late 1990s over Early } \\
1990 s\end{array}$ & $\begin{array}{c}\text { Late 2000s over Early } \\
1990 \mathrm{~s}\end{array}$ \\
\hline Barisal & 836 & 879 & 1907 & 5.15 & 128.04 \\
\hline Bogra & 1583 & 1438 & 1422 & -9.18 & -10.14 \\
\hline Chittagong & 1323 & 1601 & 2428 & 20.96 & 83.46 \\
\hline Chittagong H.T. & 1643 & 1150 & 1435 & -30.03 & -12.65 \\
\hline Comilla & 1434 & 1364 & 1353 & -4.87 & -5.66 \\
\hline Dhaka & 1082 & 791 & 1521 & -26.88 & 40.56 \\
\hline Dinajpur & 636 & 1005 & 1427 & 58.15 & 124.46 \\
\hline Faridpur & 1253 & 658 & 1521 & -47.49 & 21.39 \\
\hline Jamalpur & 1019 & 1662 & 2306 & 63.10 & 126.35 \\
\hline Jessore & 1008 & 1039 & 1972 & 3.03 & 95.66 \\
\hline Kishoreganj & 1274 & 1583 & 1481 & 24.28 & 16.25 \\
\hline Kushtia & 965 & 1124 & 1251 & 16.51 & 29.59 \\
\hline Mymensingh & 1090 & 1378 & 1201 & 26.42 & 10.19 \\
\hline Noakhali & 881 & 1103 & 1244 & 25.31 & 41.24 \\
\hline Pabna & 1321 & 1309 & 1595 & -0.93 & 20.75 \\
\hline Patuakhali & 867 & 1151 & 1095 & 32.74 & 26.29 \\
\hline Rajshahi & 4284 & 1475 & 1299 & -65.57 & -69.68 \\
\hline Rangpur & 1005 & 545 & 1511 & -45.76 & 50.41 \\
\hline Sylhet & 1147 & 1335 & 1696 & 16.37 & 47.82 \\
\hline Tangail & 889 & 906 & 1300 & 2.00 & 46.28 \\
\hline Bangladesh & 1082 & 1131 & 1504 & 4.50 & 39.04 \\
\hline
\end{tabular}

Note: Early 1990s, late 1990s and late 2000s refers to the crop year, 1990/91- 1992/93, 1999/00- 2001/02 and 2007/08- 2009/10

Source: Authors' calculation, based on data collected from BBS

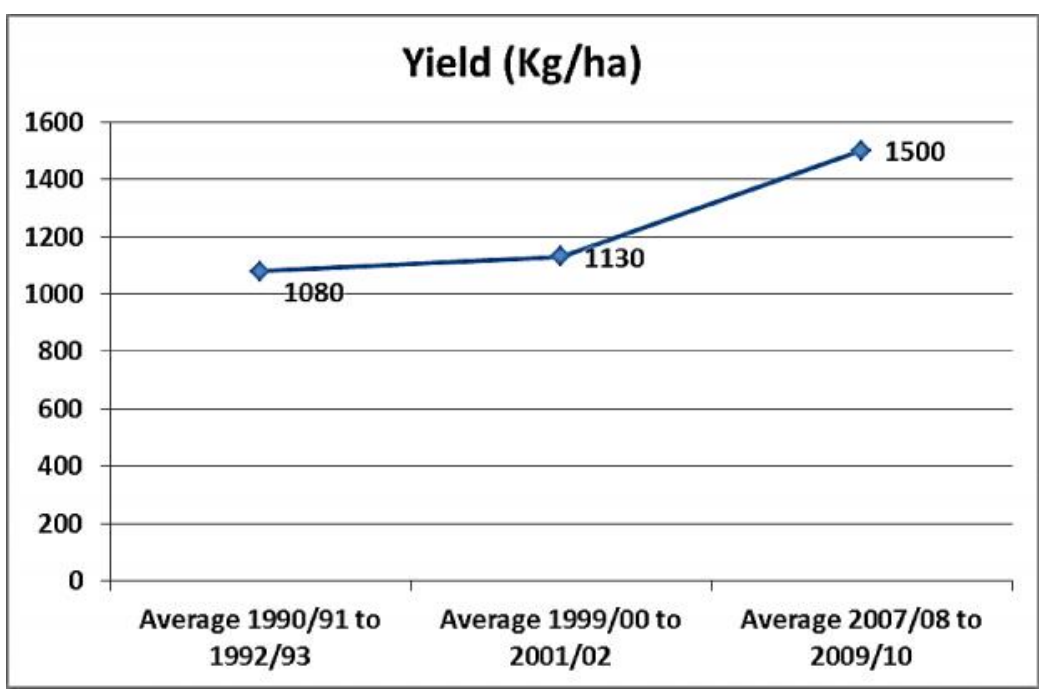

Fig. 2: Trend in Yield (Kg/ha) of Groundnut in Bangladesh, 1990/91 to 2009/10

Source: Authors' calculation, based on data collected from BBS 
Jessore, Patuakhali, Pabna, Rangpur and Chittagong H.T.) experienced negative growth in area, 8 districts (Dhaka, Jessore, Faridpur, Comilla, Dinajpur, Rajshahi, Rangpur and Chittagong H.T) experienced negative growth in production and 7 districts (Comilla, Dhaka, Faridpur, Jessore, Bogra, Rajshahi and Chittagong H.T) experienced negative growth in yield. Other districts had moderate or slow growth in area, production and yield of groundnut in the 1990s.

In the 2000s, 7 districts (Faridpur, Tangail, Jessore, Kushtia, Dinajpur, Pabna and Chittagong H.T.) experienced high growth in area and 9 districts (Faridpur, Tangail, Barisal, Jessore, Kushtia, Dinajpur, Pabna, Rangpur and Chittagong H.T.) had high growth in production and another 7 districts experienced high growth in yield (Dhaka, Faridpur, Tangail, Barisal,
Jessore, Dinajpur and Rangpur). Dinajpur experienced highest growth in area (51.44 percent) and production (60.64 percent) while Rangpur had highest growth in yield (19.72 percent). During the same period, 10 districts (Bogra, Barisal, Comilla, Sylhet, Dhaka, Jamalpur, Kishoreganj, Mymensingh, Patuakhali and Rajshahi) experienced negative growth in area and 9 districts (Dhaka, Bogra, Comilla, Sylhet, Jamalpur, Kishoreganj, Mymensing, Patuakhali and Rajshahi) had negative growth in production and 4 districts (Mymensingh, Rajshahi, Comilla and Patuakhali) had negative growth in yield.

For clear understanding of the growth scenario, we discuss the association between growth rates in groundnut area and yield (Table 4). On the basis of growth rates of area and yield, the study districts revealed

Table 3: Annual compound rate of growth (\%) in area, production and yield of groundnut in Bangladesh

\begin{tabular}{|l|c|c|c|c|c|c|}
\hline \multirow{2}{*}{ Districts } & \multicolumn{2}{|c|}{ Area } & \multicolumn{2}{c|}{ Production } & \multicolumn{2}{c|}{ Yield } \\
\cline { 2 - 7 } & $\mathbf{1 9 9 0 s}$ & $\mathbf{2 0 0 0 s}$ & $\mathbf{1 9 9 0}$ & $\mathbf{2 0 0 0 s}$ & $\mathbf{1 9 9 0 s}$ & $\mathbf{2 0 0 0 s}$ \\
\hline Barisal & 2.94 & -4.69 & 4.71 & 6.08 & 1.82 & 11.18 \\
\hline Bogra & 3.56 & -11.31 & 1.92 & -11.22 & -1.59 & 0.10 \\
\hline Chittagong & 0.80 & 0.10 & 2.74 & 4.29 & 1.92 & 4.08 \\
\hline Chittagong H.T. & -17.47 & 6.72 & -19.51 & 9.53 & -2.37 & 2.63 \\
\hline Comilla & 1.71 & -13.06 & -1.00 & -13.32 & -2.57 & -0.30 \\
\hline Dhaka & 3.36 & -8.42 & -1.29 & -2.08 & -4.50 & 7.04 \\
\hline Dinajpur & 7.68 & 51.44 & -2.57 & 60.64 & 8.22 & 6.08 \\
\hline Faridpur & -11.13 & 15.95 & -18.54 & 28.92 & -8.33 & 11.18 \\
\hline Jamalpur & -2.37 & -2.37 & 0.60 & -0.20 & 3.05 & 2.22 \\
\hline Jessore & -6.48 & 20.44 & -7.87 & 29.43 & -1.49 & 7.57 \\
\hline Kishoreganj & 1.71 & -7.13 & 7.25 & -4.02 & 5.44 & 3.36 \\
\hline Kushtia & 2.33 & 16.07 & 3.98 & 17.00 & 1.61 & 0.70 \\
\hline Mymensingh & -0.40 & -6.76 & 3.15 & -8.61 & 3.56 & -1.98 \\
\hline Noakhali & -1.69 & 0.80 & 1.51 & 2.33 & 3.25 & 1.51 \\
\hline Pabna & -0.90 & 20.44 & 0.00 & 23.74 & 0.90 & 2.74 \\
\hline Patuakhali & -0.20 & -7.60 & 3.77 & -7.87 & 4.08 & -0.30 \\
\hline Rajshahi & 5.13 & -9.52 & -6.39 & -11.57 & -10.95 & -2.18 \\
\hline Rangpur & -4.21 & 1.21 & -2.76 & 21.05 & 1.51 & 19.72 \\
\hline Sylhet & -1.49 & -9.97 & 0.60 & -6.57 & 2.12 & 3.77 \\
\hline Tangail & 4.08 & 32.05 & 4.19 & 39.51 & 0.10 & 5.55 \\
\hline Bangladesh & -1.29 & 1.11 & -0.30 & 5.13 & 1.11 & 3.98 \\
\hline
\end{tabular}

Source: Authors' calculation, based on data collected from BBS

Table 4: Association between growth rate in groundnut area and yield in different districts of Bangladesh

\begin{tabular}{|l|l|l|}
\hline Types of Association & Districts under the category during different study period \\
\cline { 2 - 3 } & $\mathbf{1 9 9 0 s}$ & $\mathbf{2 0 0 0 s}$ \\
\hline 1. AA: Positive area, positive yield & $\begin{array}{l}\text { Chittagong, Kishoreganj, Tangail, Barisal, } \\
\text { Kushtia, Dinajpur }\end{array}$ & $\begin{array}{l}\text { Chittagong, Noakhali, Faridpur, Tangail, } \\
\text { Jessore, Kushtia, Dinajpur, Pabna, Rangpur, } \\
\text { Chittagong H.T., Bangladesh }\end{array}$ \\
\hline 2. AB: Positive area, negative yield & Comilla, Dhaka, Bogra, Rajshahi & - \\
\hline 3. BA: Negative area, positive yield & $\begin{array}{l}\text { Sylhet, Noakhali, Mymensingh, Jamalpur, } \\
\text { Pabna, Patuakhali, Rangpur, Bangladesh }\end{array}$ & $\begin{array}{l}\text { Sylhet, Dhaka, Kishoreganj, Jamalpur, Bogra, } \\
\text { Barisal }\end{array}$ \\
\hline 4. BB: Negative area, negative yield & Faridpur, Jessore, Chittagong H.T. & Comilla, Mymensingh, Patuakhali, Rajshahi \\
\hline
\end{tabular}

Source: Authors' calculation, based on data collected from BBS 
four types of association: AA- positive growth rate of area associated with positive growth rate of yield. This would indicate that groundnut is either replacing other crops or is grown in the newly cultivated area and the overall yield of groundnut increased. AB-positive growth rate of area associated with negative growth rate of yield. BA- negative growth rate of area associated with positive growth rate of yield. This would indicate that groundnut area has been replaced by other crops or has gone out of cultivation and the yield of the remaining area has increased. BB- negative growth rate of area associated with negative growth rate of yield. In the 1990s, 6 districts were in category AA, 4 districts in category $\mathrm{AB}, 8$ districts in category $\mathrm{BA}$ and 3 districts fall in category BB. In 2000s, number of districts under different categories was: $\mathrm{AA}$ (10 districts), $\mathrm{AB}$ (none), BA (6 districts) and BB (4 districts). In the 1990s, Bangladesh experienced negative growth in area and positive growth in yield. In the 2000s, Bangladesh had positive growth in both area and yield indicating that groundnut had expanded to the areas suitable for this crop.

The level of instability in groundnut production is very important for sustainable production. Therefore, we have estimated the relative variability in groundnut production using equation (3). To see the significant differences in changes in CV between the two periods, we have conducted a $Z$ statistics analysis for each of the districts; following equation (4). The results of the analysis along with the calculated value of $Z$ statistics for individual districts are presented in Table 5 .

The relative variability in groundnut production in Bangladesh during the 1990s and 2000s were 2.9, and 6.6 percent, respectively, indicating an increase in production variability in the later period. However, the increase in relative variability was not statistically significant. The increase in coefficient of variation in groundnut production during 2000s, compared to 1990s, revealed that it was statistically significant only in three districts (Sylhet, Mymensingh and Tangail). Other districts had no statistically significant change in groundnut production variability. It is pertinent to mention here that these three districts together contributed only 7.8 percent to the total groundnut production of Bangladesh during the 2000s. Therefore, it appears that the major groundnut producing districts such as Noakhali, Faridpur and Dinajpur had no statistically significant change in production variability though majority of the districts experienced a decline in production variability.

Table 5: Relative variability in groundnut production in Bangladesh

\begin{tabular}{|c|c|c|c|c|}
\hline \multirow[t]{2}{*}{ District } & \multicolumn{2}{|c|}{ CV for Production } & \multirow{2}{*}{$\begin{array}{c}\text { Change in CV (percentage Point) } \\
\text { In 2000s over 1990s }\end{array}$} & \multirow{2}{*}{$\begin{array}{c}\text { Z Statistics } \\
\text { In 2000s over 1990s }\end{array}$} \\
\hline & 1990s & $2000 s$ & & \\
\hline Barisal & 5.80 & 18.85 & 13.05 & 0.86 \\
\hline Bogra & 24.31 & 18.11 & -6.20 & -0.02 \\
\hline Chittagong & 4.28 & 15.15 & 10.87 & 1.31 \\
\hline Chittagong H.T. & 73.54 & 38.59 & -34.95 & -0.01 \\
\hline Comilla & 10.68 & 22.54 & 11.86 & 0.23 \\
\hline Dhaka & 12.00 & 17.10 & 5.10 & 0.08 \\
\hline Dinajpur & 46.21 & 75.25 & 29.04 & 0.03 \\
\hline Faridpur & 11.31 & 25.46 & 14.15 & 0.25 \\
\hline Jamalpur & 11.09 & 24.98 & 13.89 & 0.25 \\
\hline Jessore & 10.74 & 54.21 & 43.47 & 0.84 \\
\hline Kishoreganj & 15.67 & 25.84 & 10.17 & 0.09 \\
\hline Kushtia & 9.79 & 23.62 & 13.83 & 0.32 \\
\hline Mymensingh & 3.53 & 14.77 & 11.24 & $1.98^{*}$ \\
\hline Noakhali & 8.68 & 4.50 & -4.18 & -0.12 \\
\hline Pabna & 22.14 & 51.60 & 29.46 & 0.13 \\
\hline Patuakhali & 25.75 & 7.41 & -18.34 & -0.06 \\
\hline Rajshahi & 73.98 & 17.76 & -56.22 & -0.02 \\
\hline Rangpur & 7.95 & 29.25 & 21.30 & 0.75 \\
\hline Sylhet & 4.80 & 32.09 & 27.29 & $2.62 * *$ \\
\hline Tangail & 5.40 & 38.64 & 33.24 & $2.52 * *$ \\
\hline Bangladesh & 2.94 & 6.58 & 3.64 & 0.91 \\
\hline
\end{tabular}

Notes: The values of $\mathrm{Z}$ are computed using equation (3) to see whether there was a statistically significant difference of CV of groundnut production (computed as in equation 2) between periods. Double star (**) indicates that computed $\mathrm{Z}$ is significant at 1 percent level of significance while a single star $(*)$ indicates the value is significant at 5 percent level of significance

Source: Authors' calculation, based on data collected from BBS 
Table 6 presents the relative variability in groundnut area in different districts of Bangladesh. The coefficient of variation in groundnut area in Bangladesh during the 1990s and 2000s were 2.24 and 7.95 percent, respectively. The increase in $\mathrm{CV}$ in groundnut area in Bangladesh in the 2000s was statistically significant at $1 \%$ level. During the 2000s, compared to 1990s, all districts except Noakhali experienced increase in variability in groundnut area while five districts (Comilla, Dinajpur, Patuakhali, Sylhet and Tangail) experienced a statistically significant increase in area variability. Noakhali district experienced statistically significant decrease in variability in groundnut area.

The magnitude of relative variability in groundnut yield in different districts of Bangladesh is presented in Table 7. The relative variability in groundnut yield in Bangladesh during the 1990s and 2000s were 3.0, and 4.7 percent, respectively. In the 2000s, compared to the 1990s, three districts (Kushtia, Rangpur and Tangail) had statistically significant increase in yield variability.

The association between groundnut yield and relative variability in yield is presented in Table 8 . We found four different types of association: AA- increase in yield associated with decrease in relative variability,
AB- increase in yield associated with increase in relative variability, BA- decrease in yield associated with decrease in relative variability, BB- decrease in yield associated with increase in relative variability. From the view point of development, AA is the best situation whereas $\mathrm{BB}$ indicates the worst situation. $\mathrm{AB}$ would be preferred to BA. In the 2000s, compared to the 1990s, 3 districts (Noakhali, Patuakhali and Chittagong H.T.) experienced an increase in yield accompanied by decrease in variability in yield while only Kishoreganj district experienced decrease in yield associated with increase in variability of yield. Three districts (Comilla, Bogra and Rajshahi) experienced decrease in yield with decrease in variability. Other districts faced increase in yield associated with increase in variability.

\section{Conclusion}

The study analyzed the trends in area, production and yield of groundnut in three specific time periods: early 1990s (1990/91- 1992/93), late 1990s (1999/002001/02) and late 2000s (2007/08- 2009/10). It has also analyzed the growth and variability in groundnut area, production and yield for two different periods: 1990s (1990/91 to 1999/00) and 2000s (2000/01 to 2009/10).

Table 6: Relative variability in groundnut area in Bangladesh

\begin{tabular}{|l|c|c|c|c|}
\hline \multirow{2}{*}{ District } & \multicolumn{2}{|c|}{ CV for area } & $\begin{array}{c}\text { Change in CV (percentage Point) } \\
\text { In 2000s over 1990s }\end{array}$ & $\begin{array}{c}\text { Z Statistics (In 2000s over } \\
\text { 1990s) }\end{array}$ \\
\cline { 2 - 4 } & $\mathbf{1 9 9 0 s}$ & $\mathbf{2 0 0 0 s}$ & 2.58 & 0.16 \\
\hline Barisal & 6.01 & 8.59 & 1.01 & 0.01 \\
\hline Bogra & 16.05 & 17.06 & 8.45 & 0.49 \\
\hline Chittagong & 6.18 & 14.63 & 6.77 & 0.02 \\
\hline Chittagong H.T. & 28.66 & 35.43 & 12.91 & $1.98^{*}$ \\
\hline Comilla & 3.78 & 16.69 & 3.96 & 0.95 \\
\hline Dhaka & 3.01 & 6.97 & 60.64 & $1.94 *$ \\
\hline Dinajpur & 8.34 & 68.98 & 15.68 & 0.43 \\
\hline Faridpur & 8.98 & 24.66 & 8.55 & 0.51 \\
\hline Jamalpur & 6.09 & 14.64 & 39.55 & 0.89 \\
\hline Jessore & 9.94 & 49.49 & 4.73 & 0.31 \\
\hline Kishoreganj & 5.83 & 10.56 & 13.19 & 0.30 \\
\hline Kushtia & 9.89 & 23.08 & 15.32 & 3.05 \\
\hline Mymensingh & 3.31 & 18.63 & -2.84 & -0.09 \\
\hline Noakhali & 8.44 & 5.60 & 36.65 & 0.35 \\
\hline Pabna & 15.28 & 51.93 & 15.25 & $6.19^{* *}$ \\
\hline Patuakhali & 2.29 & 17.54 & 10.91 & 1.44 \\
\hline Rajshahi & 4.08 & 14.99 & 3.47 & 0.15 \\
\hline Rangpur & 7.22 & 10.69 & 25.44 & $11.32^{* *}$ \\
\hline Sylhet & 2.19 & 27.63 & 24.40 & $2.74^{* *}$ \\
\hline Tangail & 4.43 & 28.83 & $\mathbf{5 . 7 1}$ & $\mathbf{2 . 4 2 * *}$ \\
\hline Bangladesh & $\mathbf{2 . 2 4}$ & $\mathbf{7 . 9 5}$ & & \\
\hline
\end{tabular}

Notes: The values of $\mathrm{Z}$ are computed using equation (4) to see whether there was a statistically significant difference of CV of groundnut yield (computed as in equation (3) between periods. Double star $\left(^{* *}\right)$ indicates that computed Z is significant at 1 percent level of significance while a single star $(*)$ indicates the value is significant at 5 percent level of significance.

Source: Authors' calculation, based on data collected from BBS 
In the late 2000s, groundnut production has increased in Bangladesh while groundnut area has decreased. Thanks to the increase in groundnut yield. Top five groundnut growing districts (Noakhali, Faridpur, Dinajpur, Dhaka and Chittagong) accounted for 58 percent of production and 60 percent of groundnut area in Bangladesh in the late 2000s. In the 1990s, both area and production of groundnut declined in Bangladesh but in the 2000s both area and production of groundnut registered positive growth. Groundnut yield consistently increased in the 1990s and 2000s. It seems that expansion of groundnut area in the 2000s took place in lands suitable for groundnut cultivation. The relative variability in groundnut production has increased in the 2000s at the national level but it was not statistically significant. Statistically significant increase in production variability in the 2000 s was observed in three low production districts (Mymensingh, Sylhet and Tangail) which were mainly due to variability in groundnut area. Three districts (Kushtia, Rangpur and Tangail) had significant increase in yield variability but they are not major groundnut producing districts. Thus, our empirical results suggest that priority should be given for increasing yield potential of groundnut in Bangladesh through agricultural research. It is because scope for increase in area under groundnut is very limited due to land scarcity and conversion of land for non-crop and non-farm enterprises.

Table 7: Relative variability in groundnut yield in Bangladesh

\begin{tabular}{|l|c|c|c|c|}
\hline \multirow{2}{*}{ District } & \multicolumn{2}{|c|}{ CV for yield } & Change in CV (percentage Point) & Z Statistics \\
\cline { 2 - 5 } & $\mathbf{1 9 9 0 s}$ & $\mathbf{2 0 0 0 s}$ & In 2000s over 1990s & In 2000s over 1990s \\
\hline Barisal & 9.73 & 17.86 & 8.13 & -0.19 \\
\hline Bogra & 10.52 & 6.11 & -4.41 & 0.09 \\
\hline Chittagong & 6.51 & 13.50 & 6.99 & -0.04 \\
\hline Chittagong H.T. & 46.94 & 12.22 & -34.72 & -0.04 \\
\hline Comilla & 9.62 & 8.03 & -1.59 & 0.06 \\
\hline Dhaka & 11.30 & 14.63 & 3.33 & 0.08 \\
\hline Dinajpur & 11.28 & 15.80 & 4.52 & 1.02 \\
\hline Faridpur & 4.00 & 11.44 & 7.44 & 0.31 \\
\hline Jamalpur & 8.34 & 18.00 & 9.66 & 0.27 \\
\hline Jessore & 10.23 & 22.86 & 12.63 & 0.03 \\
\hline Kishoreganj & 18.56 & 23.22 & 4.66 & $1.97 *$ \\
\hline Kushtia & 3.43 & 13.99 & 10.56 & 1.18 \\
\hline Mymensingh & 4.06 & 12.88 & 8.82 & -0.26 \\
\hline Noakhali & 3.60 & 2.06 & -1.54 & 0.02 \\
\hline Pabna & 9.22 & 9.99 & 0.77 & -0.04 \\
\hline Patuakhali & 25.87 & 13.95 & -11.92 & -0.02 \\
\hline Rajshahi & 77.08 & 11.93 & -65.15 & $10.43^{* *}$ \\
\hline Rangpur & 2.31 & 28.33 & 26.02 & 0.14 \\
\hline Sylhet & 6.36 & 8.87 & 2.51 & $3.18^{* *}$ \\
\hline Tangail & 2.79 & 14.19 & 11.4 & $\mathbf{0 . 3 9}$ \\
\hline Bangladesh & $\mathbf{3 . 0 4}$ & $\mathbf{4 . 6 8}$ & $\mathbf{1 . 6 4}$ & \\
\hline
\end{tabular}

Notes: The values of $Z$ are computed using equation (4) to see whether there was a statistically significant difference of CV of groundnut yield (computed as in equation (4) between periods. Double star (**) indicates that computed Z is significant at 1 percent level of significance while a single star $(*)$ indicates the value is significant at 5 percent level of significance.

Source: Authors' calculation, based on data collected from BBS

Table 8: Association between yield and variability in yield of groundnut in different districts of Bangladesh

\begin{tabular}{|l|l|}
\hline Types of Association & Districts under the category during \\
\cline { 2 - 2 } & In 2000s compared to 1990s \\
\hline 1. AA: Increase in yield with decrease in variability & Noakhali, Patuakhali, Chittagong H.T. \\
\hline 2. AB: Increase in yield with increase in variability & $\begin{array}{l}\text { Chittagong, Sylhet, Dhaka, Faridpur, Jamalpur, Mymensingh, Tangail, } \\
\text { Barisal, Jessore, Kushtia, Dinajpur, Pabna, Rangpur, Bangladesh }\end{array}$ \\
\hline 3. BA: Decrease in yield with decrease in variability & Comilla, Bogra, Rajshahi \\
\hline 4. BB: Decrease in yield with increase in variability & Kishoreganj \\
\hline
\end{tabular}

Source: Authors' calculation, based on data collected from BBS 


\section{References}

Alauddin, M, and Tisdell C.A. 1988a. Impact of New Agricultural Technology on the Instability of Foodgrain Production and Yield: Data Analysis for Bangladesh and Its Districts. Journal of Development Economics, 29: 2.

Anderson, J.R., Hazell, P.B.R. and Evans L.T. 1987. Variability of Cereal Yields-Sources of Change and Implications for Agricultural Research and Policy. Food Policy, 12(3): 199-212.

Anderson, J.R. and Hazell, P.B.R. 1989. Changing Variability in Cereal Production in Australia, In P.B.R. Hazell and J.R. Anderson (Ed.), Variability in Grain Yields: Implications for Agricultural Research and Policy in Developing Countries. Baltimore: Johns Hopkins University Press.

Barker, R.E., Gabler, E. and Winckelmann, D. 1981. Long Term Consequences of Technological Change on Crop Yield Stability: The Case for Cereal Grains. In A.Valdes (Ed.) Food Security for Developing Countries. Boulder: Westview Press.

Deb, U.K., Bose, G.K. and Dey, M.M. 1999. Growth and Variability in Sugarcane Production in Bangladesh. The Asian Economic Review, 41(1): 152-165.

Deb U.K., Joshi, P.K. and Bantilan, M.C.S. 1999. Impact of Modern Cultivars on Growth and Relative Variability in Sorghum Yields in India. Agricultural Economics Research Review, 12(2): 84-106.

Deb, U.K., Mandal, M.A.S. and Dey, M.M. 1991. Impact of New Technology on Production Variability in Bangladesh Agriculture. Bangladesh Journal of Agricultural Economics, 15(2): 27-50.

Evenson, R.E., O'Toole, J.C., Herdt, R.W., Coffman, W.R. and Kaufman, H.E. 1979. Risk and Uncertainty as Factors of Crop Improvement Research. In J.A. Roumasset, J.M. Boussard and Singh, I. (Ed.) Risk, Uncertainty and Agricultural Development. Laguna, Philippines: Southeast Asia Regional Center for Graduate Study and Research in Agriculture and the Agricultural Development Council.

Griffin, K. 1988. Alternative Strategies for Economic Development. Paris: Organization for Economic Cooperation and Development.

Hazell, P.B.R. 1985. Sources of Increased Variability in World Cereal Production since the 1960s. Journal of Agricultural Economics, 36(2): 145-159.
Hazell, P.B.R. 1969. Changing Patterns of Variability in World Cereal Production. In J.R. Anderson, and P.B.R. Hazell (Ed.) Variability in Grain Yield. Baltimore and London, The John Hopkins University Press, pp. 13-34.

Kendall, M. and Stewart, A. 1969. The Advanced Theory of Statistics. Vol. 1, Distribution Theory". (3rd Ed.) New York: Macmillan.

McIntire, J. and Fussell, L.K. 1985. Sources of Millet Grain Yield Variation and Their Research Implications. Paper presented at the IFPRI/DSE workshop on Sources of Increased Variability in Cereal Yields. Feldafing, Germany, pp. 26-29.

Mehra, S. 1981. Instability in Indian Agriculture in the Context of the New Technology. Research Report No. 25, Washington, International Food Policy Research Institute.

Nath, U.K. and Alam, M.S. 2002. Genetic variability, Heritability and Genetic Advance of Yield and Related Traits of Groundnut (Arachis Hypogaea L.). Online Journal of Biological Sciences, 2(11): 762-764.

Patil, B.N., Bhonde, S.R. and Khandikar, D.N. 2009. Trends in Area, Production and productivity of Groundnut in Maharashtra. Financing Agriculture, March-April.

Ragavendra, L.B. 2006. Changes in Oilseed Economy of Karnataka: Pre and Post-WTO Analysis. Unpublished Thesis submitted to the University of Agricultural Sciences, Dharwad, in partial fulfillment of the requirements for the Degree of Master of Business Administration.

Rao, C.H. 1975. Technological Change and Distribution of Gains in Indian Agriculture. Institute of Economic Growth, Delhi, The Macmillan Co.

Sen, S.R. 1967. Growth and Instability in Indian Agriculture. Address to the 20th Annual Conference of the Indian Society of Agricultural Statistics, pp. 1-31.

Singh, A.J. and Byerlee, D. 1990. Relative Variability in Wheat Yields Across Countries and Over Time. Journal of Agricultural Economics, 41(1): 21-32.

Weber, A. and Sievers, M. 1985. Observations on the Geography of Wheat Production Instability. Quarterly Journal of International Agriculture, 24(3): 201-211. 